\title{
Evaluation of Yard Long Bean (Vigna unguiculata ssp. sesquipedalis) Genotypes for Commercial Production in the Central Mid hills Region of Nepal
}

\author{
Suprabha Pandey, Surendra Lal Shrestha, Ishwori Prasad Gautam, Mira Dhakal and Sangita Sapkota \\ Horticulture Research Division, Khumaltar, Lalitpur, Nepal \\ Corresponding author's email: suprabhapandey52@gmail.com
}

Received on: 14 July 2019, Revised on: 3 December 2019, Accepted on: 4 January 2020

\begin{abstract}
The experiment on evaluation of open pollinated genotypes of Yard long bean (Vigna unguiculata ssp. sesquipedalis) was conducted during summer season of 2016 and 2017 at Horticulture Research Division, Khumaltar Lalitpur to assess the variability in the genotypes and yield potentiality for commercial production. The experiment was laid out in Randomized Complete Block Design with three replications. Six genotypes viz. Great Wall 01, Great Wall 02, Great Wall 03, Great Wall 04 and Great Wall 08 were compared with Khumal Tane. Observations were recorded on fresh pod yield and yield attributing parameters. The plant vigor and plant uniformity score ( $1-5$ scale) was not found significantly different among the tested genotypes. The highest number of pods per plant (46) was observed on the variety Great Wall 03 and the lowest number of pods (33) on Great Wall 01 followed by Khumal Tane (39). The fresh pod yield was noted the highest with Great wall 03 (24 t/ha) followed by Great Wall 2 (19.4 t/ha). The lowest yield was observed with Khumal Tane (12.7 t/ha). Likewise, Great Wall 03 was found tender whitish with green color when it matures and spongy type of fruit with mid early maturity (85-95 days) along with long harvesting period of 30-35 days. Although Great Wall 02 scored 4.7 in plant uniformity (1-5 scale) and 4.4 in plant vigor ( $1-5$ scale) it was characterized as thick fleshy and whitish green color at maturity with smooth straight type flesh having early maturity (70-80 days) which could gain the demand of the market early compared to most popular Khumal Tane. Thus, among all genotypes Great Wall 03 and Great Wall 02 were recorded best for further evaluation and recommendation.
\end{abstract}

Keywords: : Yard long bean, Open pollinated, Evaluation, Commercial production in Nepal

\section{Introduction}

Yard long bean (Vigna unguiculata ssp. sesquipedalis) is a distinct form of cowpea grown as a vegetable crop in southern Asia and Far East for its immature pod is characterized by its very long $(30-90 \mathrm{~cm}$ in length) pods with seeds usually $8-12 \mathrm{~mm}$ long. It is also known as asparagus bean, string bean and snake bean. Unlike other Vigna crops which are primarily grown for seeds, yard long bean is cultivated mainly for crisp and tender pods that are consumed both fresh and cooked. Yard long bean is believed to have been domesticated from cultivated cowpea in Asia (Kongjaimun, et al., 2012). In Nepal, Yard long beans are gaining popularity among marginal farmers in recent years due to its multipurpose use. Its area of production is increasing annually because of its commercial value and higher yield. It is cultivated in 4539 ha with total production and

Copyright (C) 2020 Nepal Horticulture Society. This article is licensed under Creative Commons Attribution 4.0 International License. This permits unrestricted use, distribution and reproduction in any medium provided the original work is properly cited. 
productivity of $88649.5 \mathrm{mt}$ and $19.5 \mathrm{mt} /$ ha respectively (MOAD 2016). Productivity of Yard long bean is much lower in Nepal due to the unavailability of quality seed and poor management of crop.

Thus, at present, Nepalese commercial fresh vegetable growers are attracted towards yard long bean due to its short growing period with long harvestable nature and high demand among consumers. The current research was initiated with the objectives of doing collection, evaluation and characterization of available exotic and indigenous germplasms so that they can be utilized for varietal improvement and commercial cultivation. Very few varieties of Yard long bean are recognized in Nepal till date. The crop is popular among Nepalese farmers for commercial production as the demand of the consumers is increasing in the present context. Thus, the new high yielding genotypes with desirable traits are to be studied in our condition for its further recommendation.

\section{Materials And Methods}

Six open pollinated genotypes were evaluated at the Horticulture Research Division (HRD), Khumaltar, lalitpur and the agro-morphological characteristics were recorded. The experimental site is at an elevation of $1332 \mathrm{~m}$ amsl and is characterized by a sub-tropical climate.. The experiment was arranged in a randomized complete block design. The treatments consisted of six genotypes viz. Great Wall 01, Great Wall 02, Great Wall 03, Great Wall 04, Great Wall 08 and Khumal Tane with three replications. Spacing was maintained at $120 \times 30 \mathrm{~cm}$. The crop was planted in April 2016 and 2017 consecutively. Manure and fertilizer were applied as compost (15 t/ha) and 80:120:60 kg.ha-1 N, $\mathrm{P}$, and $\mathrm{K}$, respectively. Scoring of agro-morphological characters was done according to the procedures given in the IBPGR (International Board for Plant Genetic Resources) descriptors (IBPGR, 1982). Observations of five randomly selected sample plants from the net plot were recorded on fresh pod yield and yield attributing parameters. Plant vigor indicating relative degree of foliage mass and uniformity indicating homogeneity of growth pattern was recorded at about $50 \%$ flowering stage using 1 to 5 rating scale. Virus and rust scoring was also done by using 1-5 scale. The data were analyzed using Genstat software (version 12.1, VSN International, Hemel Hempstead, UK).

\section{Results And Discussion}

\section{Plant Uniformity and Plant vigor}

The relative degree of foliage mass of a genotype is plant vigor. High plant vigor means high vegetative growth. Vigor was recorded at flowering using 1 to 5 rating scale. 1 for very week, 2 for weak, 3 for medium, 4 for vigorous and 5 for very vigorous. Excellent plant vigor was found in Great Wall 01 at flowering followed by Great Wall 08.

The homogeneity of growth pattern refers to the plant uniformity. It was recorded by using 1 to 5 rating scale: 1 for very poor, 2 for poor, 3 for fair, 4 for good and 5 for excellent. The plant vigor score and plant uniformity score was not found significantly different among the genotypes.

\section{Plant Vigor}

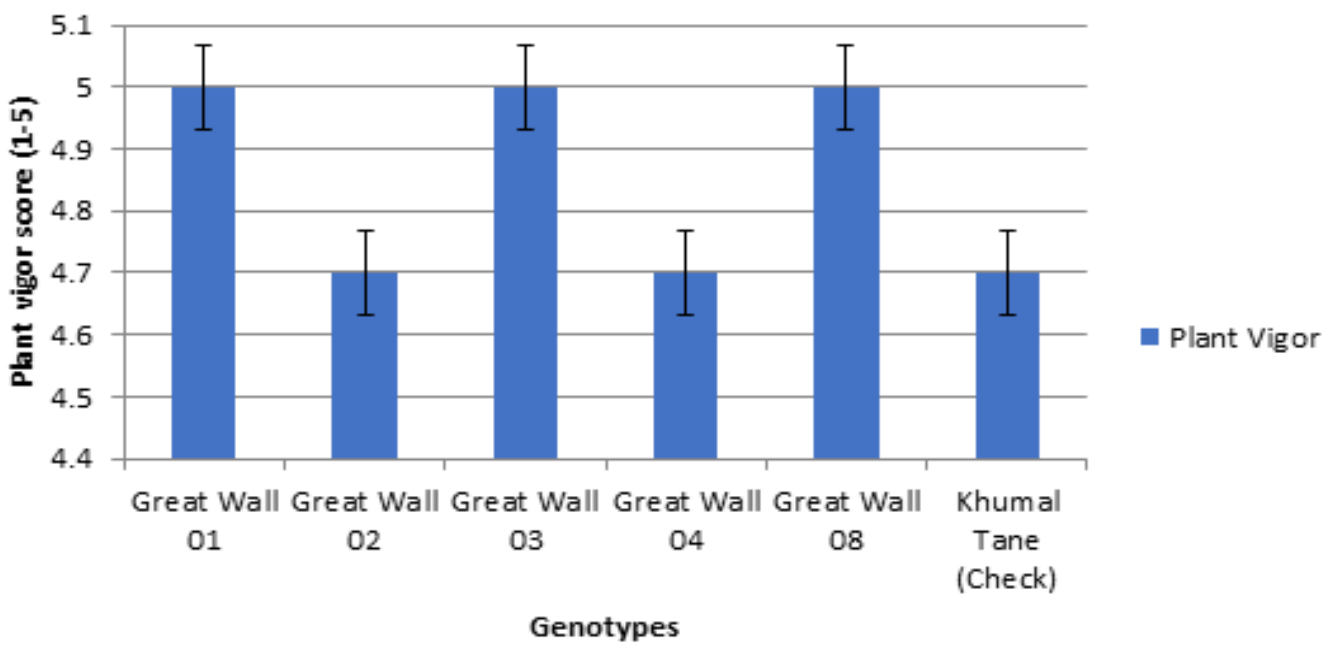

Figure 1: Plant vigor score of different genotypes of yard long bean visually observed at $50 \%$ flowering stage in the year 2016 and 2017 


\section{Plant Uniformity}

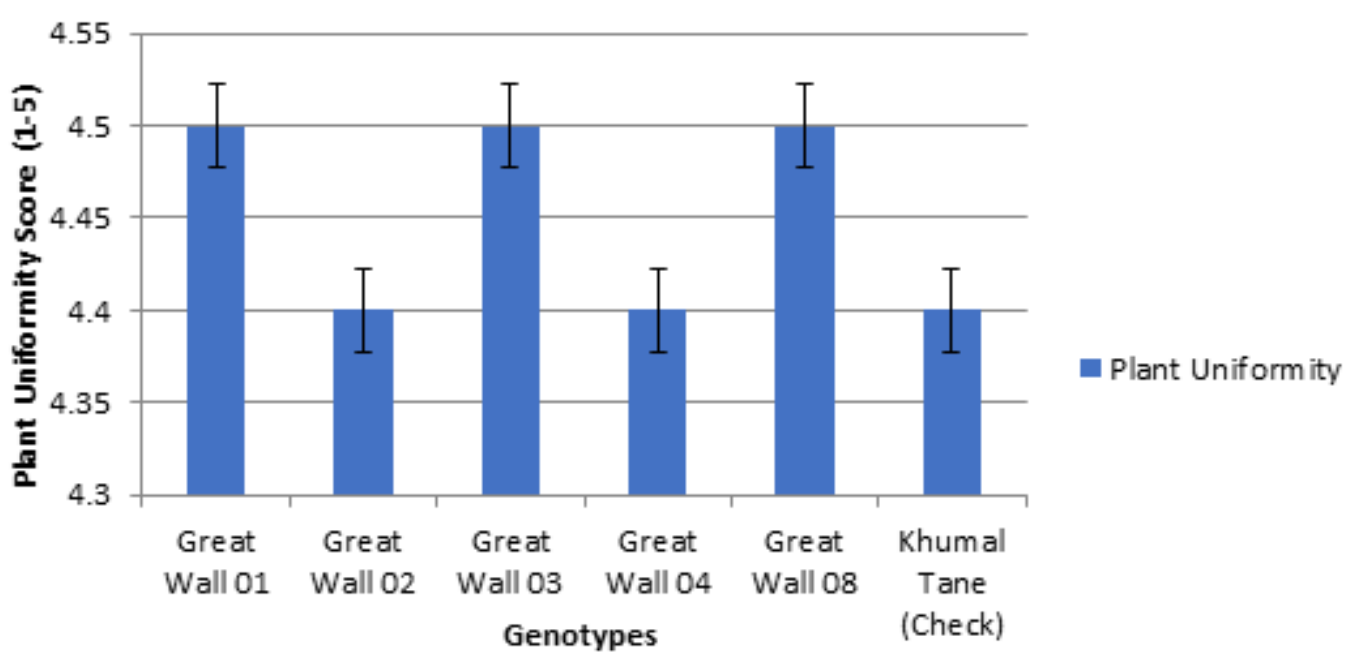

Figure 2: Plant uniformity score of different genotypes of yard long bean visually observed at full emergence and flowering in the year 2016 and 2017

\section{Number of pods per plant and total yield (gm/plant)}

Significantly the highest number of pods per plant (46) was observed on the genotype Great Wall 03 and the lowest number of pods (33) on Great Wall 01 followed by Khumal Tane (39).The number of pods per plant is correlated with the yield which can be considered as one of the yield attributing parameters. The combined analysis of both the year data showed the total yield per plant was recorded the highest in Great Wall 03 (1014.35 gm/plant) followed by Great Wall 08 (792 $\mathrm{gm} /$ plant) which is higher compared to check variety Khumal Tane (514.15 gm/plant). These results were in agreement with Jana et al. They found that number of pods per plant had the highest direct effect on pod yield per plant. Kutty et al. determined that number of pods per plant, number of pickings, average pod weight and pod length had positively and significantly correlated with yield per plant.

\begin{tabular}{|c|c|c|c|c|c|c|}
\hline \multirow{2}{*}{$\begin{array}{c}\text { Cultivars } \\
\text { Year }\end{array}$} & \multicolumn{3}{|c|}{ No. of pods/plant } & \multicolumn{3}{|c|}{ Total yield (gm/plant) } \\
\hline & 2016 & 2017 & Mean & 2016 & 2017 & Mean \\
\hline Great Wall 01 & 35 & 31 & 33 & 744 & 567.7 & 655.85 \\
\hline Great Wall 02 & 50 & 42 & 40 & 941 & 568.3 & 754.65 \\
\hline Great Wall 03 & 55 & 37 & 46 & 1364 & 664.7 & 1014.35 \\
\hline Great Wall 04 & 66 & 36 & 52 & 952 & 534.0 & 743.00 \\
\hline Great Wall 08 & 55 & 28 & 42 & 1127 & 457.0 & 792.00 \\
\hline KhumalTane (Check) & 35 & 44 & 39 & 627 & 401.3 & 514.15 \\
\hline GM & 49.3 & 36.3 & 42 & 959.1 & 532.1 & 745.66 \\
\hline F-test & * & ns & * & * & ns & * \\
\hline LSD (0.05) & 0.89 & - & 3.3 & 117.1 & - & 95.2 \\
\hline $\mathrm{CV} \%$ & 14.4 & 2.6 & 4.4 & 6.9 & 15.4 & 9.8 \\
\hline
\end{tabular}

\section{Fresh pod yield}

While observing the fresh pod yield among Yard long bean genotypes , the highest yield was noted with Great Wall 03 (24 t/ha) and it was significantly at par with Great Wall 02 (19.4 t/ha) while the lowest yield was observed with Khumal Tane $(12.7 \mathrm{t} / \mathrm{ha})$. The results revealed that the fresh pod yield was influenced by the genotype. Similar results were also reported by other researchers. Neupane et al. (2008) reported that the pod and dry seed yield in beans was influenced by the genotype. According to this study, the pod yield is not directly correlated with the pod length and pod width but it shows the relation with the number of pods per plant. 


\begin{tabular}{|l|l|l|l|}
\hline \multicolumn{4}{|c|}{ Table 2: Yield of Yard long bean at HRD, Khumaltar during the years 2016 \& 2017} \\
\hline \multicolumn{1}{|c|}{ Cultivars } & \multicolumn{1}{c|}{ Yield (t/ha) } \\
\hline \multicolumn{1}{|c|}{ Year } & \multicolumn{2}{c|}{$\mathbf{2 0 1 6}$} & \multicolumn{1}{c|}{ Mean } \\
\hline Great Wall 01 & 19.4 & 14.4 & 16.7 \\
\hline Great Wall 02 & 24.6 & 14.2 & 19.4 \\
\hline Great Wall 03 & 31.4 & 16.6 & 24 \\
\hline Great Wall 04 & 21.3 & 14.1 & 17.4 \\
\hline Great Wall 08 & 27.0 & 15.5 & 19.2 \\
\hline Khumal Tane (Check) & 15.5 & 14.1 & 12.7 \\
\hline Grand Mean & 23.1 & 14.8 & 17.4 \\
\hline F Test & $*$ & $* * *$ & $* * *$ \\
\hline LSD & 2.46 & 1.48 & 1.33 \\
\hline CV \% & 5.8 & 5.5 & 4.2 \\
\hline
\end{tabular}

\section{Rust and Virus susceptibility}

Rust and virus susceptibility in six genotypes of Yard long bean was scored with 1-5 scale: 1 for no virus and rust attack and 5 for higher attack at 90 days after transplanting in both year 2016 and 2017 after first harvest of the crop. The virus and rust seems to attack the legume vegetable after the vegetative stage. In all genotypes rust and virus was not found significantly susceptible. Great Wall 02 and Great Wall 03 scored less compared to other genotypes as shown in table 3.

\begin{tabular}{|l|l|l|l|l|l|l|}
\hline \multicolumn{6}{|c|}{ Table 3: Rust and virus susceptibility of Asparagus Bean /Yard Long Bean at HRD, Khumaltar } \\
\hline \multicolumn{1}{|c|}{ Cultivars } & \multicolumn{2}{|c|}{ Rust } & \multicolumn{3}{c|}{ Virus } \\
\hline \multicolumn{1}{|c|}{ Year } & \multicolumn{1}{|c|}{$\mathbf{2 0 1 6}$} & $\mathbf{2 0 1 7}$ & \multicolumn{1}{c|}{ Mean } & $\mathbf{2 0 1 6}$ & $\mathbf{2 0 1 7}$ & Mean \\
\hline Great Wall 01 & 2.3 & 2.3 & 2.3 & 1.7 & 2.6 & 2.1 \\
\hline Great Wall 02 & 2 & 1.6 & 1.8 & 2.0 & 0.3 & 1.1 \\
\hline Great Wall 03 & 2.3 & 2.0 & 2.1 & 1.7 & 0.3 & 1.0 \\
\hline Great Wall 04 & 2.7 & 1.6 & 2.1 & 2.7 & 0.6 & 1.6 \\
\hline Great Wall 08 & 3.0 & 2.6 & 2.8 & 2.7 & 00 & 1.3 \\
\hline Khumal Tane (check) & 2.7 & 3.0 & 2.8 & 2.0 & 0.3 & 1.3 \\
\hline
\end{tabular}

\section{Conclusion}

To speed up variety introduction to farmers, on-farm yard long bean experiments were conducted and Great Wall 03 recorded the highest yield followed by Great Wall 02. Introduction of high yielding varieties with the desired traits could commercialize the production and could contribute to the improved food security. Results gathered from this study can be utilized for release and registration of the promising genotype regarding further recommendation.

\section{References}

IBPGR. 1982. Descriptor List for Phaseolus vulgaris L. International Board for Plant Genetic Resources, Rome. 32 pp.

Kongjaimun,A., Kaga, A., Tomooka, N., Somta,p., Duncan, A., Vaughan, etal.(2012).The genetics of domestication of Yard long bean. Program in plant breeding, Faculty of Agriculture at Kamphaeng Saen Kasetsart University

Kutty, C.N., R. Mili and U. Jaikumaran, 2003. Correlation and path coefficient analysis in vegetable cowpea (Vigna unguiculata (L.) Walp.). Ind. J. Hortic., 60: 257-261. 
Jana, S., M.G. Som and N.D. Das, 1983. Correlation and path analysis of vegetable pod yield components in cowpea (Vigna unguiculata var. sesquipedalis). Hayrana J. Hortic. Sci.,12:224227.

MOAD 2016. Statistical information on Nepalese agriculture 2073/74(2016.17).Ministry of Agriculture and Livestock Development Singhadurbar Kathmandu Nepal

Neupane, R. K., R. Shrestha, M. L. Vaidya, E. M. Bhattarai and R. Darai. 2008. Agromorphological diversity in common bean (Phaseolus vulgaris L.) landraces of Jumla, Nepal. 